\title{
Energy and nutrient intake in patients with chronic obstructive pulmonary disease hospitalized owing to an acute exacerbation
}

\author{
Pia Sundvall, AnneMarie Grönberg, Lena Hulthén and \\ Frode Slinde
}

Department of Clinical Nutrition, Sahlgrenska Academy at Göteborg University, Sweden

\begin{abstract}
Background: Patients with chronic obstructive pulmonary disease (COPD) are prone to frequent exacerbations, an important cause of hospital admission. A poor dietary intake during these periods has been suggested as a contributory factor to the development of malnutrition, which is common in COPD.

Objective: To assess dietary intake and nutritional status in hospitalized COPD patients.

Design: Dietary intake and anthropometric measures [e.g. body mass index (BMI) and fat-free mass index (FFMI) based on skinfold measurements] were examined in patients with COPD $(n=30)$ admitted to a pulmonary department at Sahlgrenska University Hospital, Göteborg, owing to an acute exacerbation.

Results: Seventeen of the patients had a BMI $<22 \mathrm{~kg} \mathrm{~m}^{-2}$, and $53 \%$ of the women and $76 \%$ of the men had a FFMI lower than suggested reference values. The patients who received an enriched diet or took nutritional supplements had a significantly $(p<0.01)$ higher mean (SD) energy intake/resting energy expenditure compared with patients on an ordinary hospital diet, $1.40(0.37)$ and $1.09(0.16)$, respectively. Mean intake of protein was also higher in the patients on an enriched diet/nutritional supplements $(p<0.01)$. Patients taking complete nutritional supplements had a higher intake of several micronutrients.

Conclusion: Enrichment of the diet and nutritional supplements may help to combat the low intake of energy and protein found in COPD patients hospitalized owing to an exacerbation.
\end{abstract}

Keywords: chronic obstructive pulmonary disease; exacerbation; hospital; nutritional supplement

Received: 18 May 2005; Revised: 7 Jun. 2005; Accepted: 8 Jun. 2005

\section{Introduction}

Weight loss is common among patients with chronic obstructive pulmonary disease (COPD) owing to increased energy expenditure and decreased appetite and thereby energy intake. Energy expenditure is increased: resting energy expenditure (REE), dietinduced thermogenesis and energy expenditure of physical activity (1-5). During acute exacerbation of the disease, often including inflammation (6), energy expenditure has been shown to be increased $(7,8)$ and appetite is affected negatively, owing to dyspnoea and early satiety (8).

The prevalence of malnutrition in patients with COPD has been reported to be between 20 and 50\% (9-14). Malnutrition affects pulmonary function negatively and also the ability to perform physical activity $(3,15)$. Malnutrition in COPD has also been shown to have a negative impact on the immune system and increases the mortality risk $(16,17)$.

Individual studies have shown that dietary intervention in patients with COPD increased energy intake and body weight $(18,19)$, improved pulmonary function $(7,20)$, enhanced exercise capacity (19) and improved body composition (21). However, a recent Cochrane review, including 11 studies, concluded that nutritional support had no significant effects on anthropometric measures, lung function or exercise capacity in patients with stable COPD (22).

Depleted COPD patients are recommended to increase their energy intake to 1.7 of REE or 
more (5) and protein intake should exceed $1.5 \mathrm{~g} \mathrm{~kg}^{-1} \mathrm{day}^{-1}$ (8). Knowledge about how these recommendations are implemented in daily clinical practice is limited. The aim of this study was to assess food intake and nutritional status in patients with COPD hospitalized owing to an acute exacerbation.

\section{Materials and methods}

\section{Study design}

All COPD patients $(n=39)$ admitted to a pulmonary department at Sahlgrenska University Hospital, Göteborg, owing to an acute exacerbation during a 10 week period were asked to participate in the study. A full-time dietitian (PS) was responsible for completing the dietary registrations. When the dietitian was absent, the staff at the department registered the intake. The dietitian was instructed not to intervene on nutritional assessment or treatment as this was done by the ordinary consultancy dietitian affiliated to the department. Dietary intake should be registered during the whole hospital stay for each patient, but the maximum number of registration days was set to seven. Patients were not asked to participate if, in addition to COPD, they had lung cancer or dementia, or if they did not speak Swedish. Thirty patients accepted to participate in the study and gave written informed consent. The study was approved by the Ethics Research Committee of Göteborg University.

\section{Dietary assessment}

A food and fluid registration form regularly used at the department was used to register the patients' dietary intake. The registration form consists of five parts: breakfast, lunch, dinner, in-between meals and fluid. For breakfast, lunch and dinner, portion size ordered from the kitchen was filled in, and after completing the meal, the proportion of the ordered meal ingested by the patients was assessed $(25,50$, 75 or $100 \%$ ). For in-between meals, type, amount and time of ingestion were recorded. Nutrients were calculated using a computer program, Dietist (Kost och Näringsdata, Bromma, Sweden), using the Swedish Food Data Base (1997) from the Swedish National Food Administration (23). Data on the nutrient content of dietary supplements were added to the database. Six patients were admitted to the department twice or more during the study period. Dietary registrations were performed during all stays, but only the first period is presented in this study. REE was calculated using gender, age, body weight and height (24). Calculated energy intake was divided by REE to assess the level of energy intake (EI/REE). This procedure allows the pertinence of the calculated EI to be evaluated.

\section{Anthropometry}

Anthropometric measurements included body weight, height, midarm circumference and skinfolds at four different sites. All anthropometric measurements were performed by the same trained dietitian (PS). Body weight was measured on a transportable sitting scale at the start and end of the dietary registration period. One of the patients had liver failure and oedema at the study start. This patient's body weight is not included in this study. Study end body weight was missing for seven patients (one patient deceased, for two patients body weight measurement was too strenuous, and four patients were discharged without body weight measurement). Body height was measured in 11 patients and found in the hospital record for 16 patients, and self-reported height was used for three patients.

Skinfolds were measured using a Harpenden calliper, and in addition to triceps skinfold, biceps, suprailiac and subscapular skinfolds were measured. All measurements were performed three times on the right-hand side of the body, except for five patients who were measured on the left hand side, for practical reasons. Midarm circumference and triceps skinfold were used to calculate arm muscle circumference (AMC) (25). The mean value of the three measurements was calculated and the four skinfolds were used for calculation of fat mass and fat-free mass (26). Fat-free mass index (FFMI) was calculated as fat-free mass $(\mathrm{kg})$ divided by square body height $\left(\mathrm{m}^{2}\right)(27)$. Reference values used for comparison in the current study were $15.6 \mathrm{~kg} \mathrm{~m}^{-2}$ for women and $16.7 \mathrm{~kg} \mathrm{~m}^{-2}$ for men, as suggested by Kyle et al. (27).

\section{Pulmonary function}

Habitual pulmonary function was judged by the forced expiratory volume in one second $\left(\mathrm{FEV}_{1}\right)(\%$ predicted) which was recorded in the patient's hospital record before the current hospitalization.

\section{Statistics}

All data are presented as mean and standard deviation (for normally distributed variables) or 
median and range (for skewed variables). A power calculation, based on each nutrient's coefficient of variation between subjects and within subjects, was performed for each nutrient (28). The nutrients achieving a power of more than $70 \%$ are presented. Mann-Whitney $U$-tests were used to investigate differences between genders and between patients receiving nutritional supplements or not. Fisher's exact test was used to compare the proportion of groups with a nutrient intake below the estimated average requirement. Nutritional status and intake were correlated to pulmonary function and length of hospital stay using the Pearson correlation coefficient.

\section{Results}

The mean age of the patients was 70 years, mean habitual $\mathrm{FEV}_{1}$ was $29 \%$ predicted, and they had a mean BMI of $22.3 \mathrm{~kg} \mathrm{~m}^{-2}$ (Table 1). All patients, except for one $\left(\mathrm{FEV}_{1}=56 \%\right.$ predicted $)$ had $\mathrm{FEV}_{1}$ $<50 \%$ predicted, and following European guidelines were diagnosed as having severe COPD (29). No gender differences were detected in anthropometry or pulmonary function. Seventeen patients $(57 \%)$ had a BMI $<22 \mathrm{~kg} \mathrm{~m}^{-2}$. Compared with reference values, a lower FFMI was found in $53 \%$ of the women and $76 \%$ of the men. The median length of the current hospital stay was 6 days (range 2-31) and the median number of admissions during the last year was three (range 1-21). There was no relation between length of current hospital stay and BMI $(r=-0.19$, ns $)$ or FFMI $(r=-0.15$, ns). Both BMI and FFMI correlated well with pulmonary function $(r=0.58, p<0.01$, and $r=0.43$, $p<0.05$, respectively).

Table I. Patient characteristics

\begin{tabular}{lll}
\hline & $\begin{array}{l}\text { Women } \\
(n=19)\end{array}$ & $\begin{array}{l}\text { Men } \\
(n=\mathrm{II})\end{array}$ \\
\hline Age (years) & $69(9)$ & $71(\mathrm{I0})$ \\
Body weight $(\mathrm{kg})^{\mathrm{a}}$ & $59.7(16.5)$ & $65.3(17.7)$ \\
BMI $\left(\mathrm{kg} \mathrm{m}^{-2}\right)$ & $23.3(6.7)$ & $21.4(4.8)$ \\
FEV $\left(\%\right.$ pred.) $_{\text {AMC }(\mathrm{cm})}$ & $29(10)$ & $29(9)$ \\
FFMI $\left(\mathrm{kg} \mathrm{m}^{-2}\right)$ & $21(3)$ & $23(3)$ \\
\hline
\end{tabular}

Data are means (SD).

${ }^{a}$ Body weight at start of dietary registration.

BMI: body mass index; $\mathrm{FEV}_{\mathrm{l}}$ : forced expiratory volume in one second; $\mathrm{AMC}$ : arm muscle circumference; FFMI: fat-free mass index.
Mean (SD) energy intake was 6.5 (1.8) MJ for women and $8.1(0.9) \mathrm{MJ}$ for men $(p<0.05)$. This resulted in a mean (SD) EI/REE of $1.23(0.39)$ for women and $1.29(0.20)$ for men (ns). Sixteen of the patients $(48 \%)$ received an energy- and proteinenriched hospital diet and/or liquid nutritional supplements. Mean (SD) EI/REE for those receiving enriched diet/nutritional supplements was 1.40 $(0.37)$ and for those on an ordinary hospital diet without supplements $1.09(0.16)(p<0.01)$.

Mean (SD) intake of protein was $1.2(0.4)$ $\mathrm{g} \mathrm{kg}^{-1}$ day $^{-1}$ and there were no significant differences between genders. Only four of the patients had a protein intake exceeding $1.5 \mathrm{~g} \mathrm{~kg}^{-1} \mathrm{day}^{-1}$. Mean (SD) protein intake for those receiving enriched diet/nutritional supplements was $1.3(0.4)$ $\mathrm{g} \mathrm{kg}^{-1}$ day $^{-1}$ and for those on an ordinary hospital diet without supplements $1.0(0.3)(p<0.05)$. Eleven of the patients ingested complete nutritional supplements, i.e. supplements containing vitamins and minerals in addition to energy. These 11 patients had a significantly higher intake of iron, calcium and riboflavin $(p<0.05)$ than the rest of the group. There was no statistical significant difference in the proportion of the group who had a nutrient intake below estimated average requirement between patients who ingested complete nutritional supplements and those who did not (Table 2). Patients ingesting complete nutritional supplements had a lower $\mathrm{FEV}_{1}$ (24 vs 32\%, $p<0.05$ ), lower BMI (17.8 vs $\left.25.4 \mathrm{~kg} \mathrm{~m}^{-2}, p<0.01\right)$ and lower FFMI $(13.7 \mathrm{vs}$ $\left.16.7 \mathrm{~kg} \mathrm{~m}^{-2} p<0.01\right)$ than the other patients. The difference in length of current hospital stay between the groups (13 vs 6 days) did not reach statistical significance.

\section{Discussion}

In this study of a population of patients with COPD admitted to hospital owing to an acute exacerbation, a high prevalence of low BMI and low FFMI were described. Fifty-three per cent of the women and $76 \%$ of the men had an FFMI lower than reference values. A low fat-free mass has been shown to impair exercise performance $(31,32)$, reduce health-related quality of life (33) and increase mortality $(16,34)$. COPD, in advanced stages of the disease, means frequent hospital admissions and also in some cases a long duration of hospital stay. Underweight is demonstrated as a factor that is likely to identify patients who are at increased risk for generating high costs due to hospitalization (35). 
Table 2. Proportion of patient group (\%) having a total nutrient intake below the estimated average requirement (30)

\begin{tabular}{|c|c|c|c|c|}
\hline & \multirow{2}{*}{$\begin{array}{l}\text { Patients receiving complete } \\
\text { nutritional supplements } \\
(n=I I)\end{array}$} & \multirow{2}{*}{$\begin{array}{l}\text { Patients not receiving complete } \\
\text { nutritional supplements } \\
(n=19)\end{array}$} & \multicolumn{2}{|c|}{ Estimated average requirement } \\
\hline & & & Women & Men \\
\hline Folate & 55 & 47 & $200 \mu \mathrm{g}$ & $200 \mu \mathrm{g}$ \\
\hline Iron & 18 & 16 & $6 \mathrm{mg}^{\mathrm{a}}$ & $7 \mathrm{mg}$ \\
\hline Niacin equivalent & 9 & 0 & I $2 \mathrm{NE}$ & I $5 \mathrm{NE}$ \\
\hline Riboflavin & 36 & 21 & $1.1 \mathrm{mg}$ & $1.4 \mathrm{mg}$ \\
\hline Thiamin & 36 & 26 & $0.9 \mathrm{mg}$ & $1.2 \mathrm{mg}$ \\
\hline Vitamin $B_{6}$ & 18 & 5 & $1.0 \mathrm{mg}$ & $1.3 \mathrm{mg}$ \\
\hline Vitamin C & 9 & 26 & $50 \mathrm{mg}$ & $60 \mathrm{mg}$ \\
\hline Vitamin E ( $\alpha$-tocopherol) & 27 & 11 & 5 & 6 \\
\hline Zinc & 0 & 0 & $5 \mathrm{mg}$ & $6 \mathrm{mg}$ \\
\hline
\end{tabular}

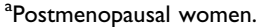

In this study the median number of hospital admissions during the past year was three and the median length of the current hospital stay was 6 days, ranging from 2 to 31 days. Three of the patients stayed more than 21 days at the hospital. Statistics from the Swedish National Board of Health and Welfare (Socialstyrelsen) show that the mean duration of a hospital stay in Sweden between 1997 and 2002 was rather stable, at 5 days (36). For diseases of the respiratory system the mean duration of hospital stay was 6 days, which is similar to the current study. The combination of recurrent hospital admissions and long duration of the hospital stay make large demands on the nutrition provided by the caregiver to the patients.

A limitations with the current study is the use of subjective measurements. Efforts were made to limit possible errors arising from this. All skinfold measurements were performed by the same trained dietitian to eliminate between-measurer variation. Fat-free mass has been shown to be overestimated in patients with chronic diseases, compared with other measures of body composition (37). This has also been shown in patients with COPD (38). However, this overestimation can be mitigated when the data are expressed as FFMI (39), which is the main outcome variable in the current study.

Despite enrichment of the hospital diet and the use of nutritional supplements, the energy intake in the total patient group was considerably lower than the recommended 1.7 times REE (5). Only two patients had an intake of energy exceeding 1.7 times REE. However, a significantly higher energy intake was observed in the patients receiving enrichment/ nutritional supplements compared with those on an ordinary hospital diet. Protein intake was also higher in patients receiving enrichment/nutritional supplements compared with those on an ordinary hospital diet. In addition to these results, patients receiving complete nutritional supplements had a higher intake of several micronutrients. Despite this, a large proportion of the patients, both with supplements and on the ordinary hospital diet, had a nutrient intake below the estimated average requirement. This is mainly due to loss of appetite, as an effect of which a large amount of the portion is left on the plate at the end of a meal.

Folate was the most common nutrient to be consumed in insufficient quantities. The mean intake of fruit and vegetables, which is the main source of folate, was $200 \mathrm{~g} \mathrm{day}^{-1}$. Three patients had an intake exceeding $400 \mathrm{~g}_{\text {day }}{ }^{-1}$. In addition to encouraging increased intake of fruit and vegetable, supplementation of folate should be considered for this patient group. Many of the patients complained of constipation. Dietary fibre has been shown to improve bowel movement frequency in adults with chronic constipation to the same degree as laxatives (40). Mean (SD) intake of fibre in the current study was $1.6(0.5) \mathrm{g} \mathrm{MJ}^{-1}$ and none of the patients achieved the recommended intake at $3 \mathrm{~g} \mathrm{MJ}^{-1}$ (30). In addition to encouraging increased intake of food rich in fibre, supplementation of fibre should be considered for this patient group. It should, however, be controlled to ensure that the increased intake of fibre does not result in a lower intake of energy or protein.

This study indicates that enrichment of the ordinary hospital diet or use of nutritional supplements can improve the dietary intake of patients with COPD admitted owing to an acute exacerbation. Patients receiving complete 
nutritional supplements had more severe COPD, a lower BMI and a lower FFMI compared with patients not receiving such supplements. Some of the patients who did not receive supplements also had a low BMI and FFMI; one patient not receiving supplements had a BMI of $17.4 \mathrm{~kg} \mathrm{~m}^{-2}$ and an FFMI of $13.8 \mathrm{~kg} \mathrm{~m}^{-2}$. It seems as if, compared with medical ordination, nutritional ordinations are considered to be a luxury service that does not need to be either followed or followed up. The recently published report "Näringsproblem i vård och omsorg - prevention och behandling", (Nutritional problems in care - prevention and treatment) states that food is a part of treatment and care for all patients (41). One of the conclusions of the report was that more education, to all groups in the care system, is necessary to achieve improvements in the identification, assessment and treatment of nutritional problems (41). This was also the result of the current study. The caregiver decided, with the background of this study, to start educational efforts to improve the knowledge about nutrition and nutritional problems in all positions at the department. The current study needs to be followed by studies on the effects of nutritional care organization and education on dietary intake, nutritional status and the total strain on the health-care system.

\section{References}

1. Schols AM, Fredrix EW, Soeters PB, Westerterp KR, Wouters EF. Resting energy expenditure in patients with chronic obstructive pulmonary disease. Am J Clin Nutr 1991; 54: 983-7.

2. Goldstein S, Askanazi J, Weissman C, Thomashow B, Kinney JM. Energy expenditure in patients with chronic obstructive pulmonary disease. Chest 1987; 91: 222-4.

3. Goldstein SA, Thomashow BM, Kvetan V, Askanazi J, Kinney JM, Elwyn DH. Nitrogen and energy relationships in malnourished patients with emphysema. Am Rev Respir Dis 1988; 138: 636-44.

4. Green JH, Muers MF. The thermic effect of food in underweight patients with emphysematous chronic obstructive pulmonary disease. Eur Respir J 1991; 4: 8139.

5. Baarends EM, Schols AM, Pannemans DL, Westerterp KR, Wouters EF. Total free living energy expenditure in patients with severe chronic obstructive pulmonary disease. Am J Respir Crit Care Med 1997; 155: 549-54.

6. Dentener MA, Creutzberg EC, Schols AM, Mantovani A, van't Veer C, Buurman WA, et al. Systemic antiinflammatory mediators in COPD: increase in soluble interleukin 1 receptor II during treatment of exacerbations. Thorax 2001; 56: 721-6.

7. Saudny-Unterberger H, Martin JG, Gray-Donald K. Impact of nutritional support on functional status during an acute exacerbation of chronic obstructive pulmonary disease. Am J Respir Crit Care Med 1997; 156: 794-9.

8. Vermeeren MA, Schols AM, Wouters EF. Effects of an acute exacerbation on nutritional and metabolic profile of patients with COPD. Eur Respir J 1997; 10: 2264-9.

9. Wilson NL, Wilson RHL, Farber SM. Nutrition in pulmonary emphysema. J Am Diet Assoc 1965; 45: 5306.

10. Hunter AM, Carry MA, Larsh HW. The nutritional status of patients with chronic obstructive pulmonary disease. Am Rev Respir Dis 1981; 124: 376-81.

11. Openbrier DR, Irwin MM, Rogers RM, Gottlieb GP, Dauber JH, van Thiel DH, et al. Nutritional status and lung function in patients with emphysema and chronic bronchitis. Eur Respir J 1983; 83: 17-22.

12. Engelen MP, Schols AM, Baken WC, Wesseling G, Wouters EF. Nutritional depletion in relation to respiratory and peripheral skeletal muscle function in outpatients with COPD. Eur Respir J 1994; 7: 1793-7.

13. Schols AM, Soeters PB, Dingemans AM, Mostert R, Frantzen PJ, Wouters EF. Prevalence and characteristics of nutritional depletion in patients with stable COPD eligible for pulmonary rehabilitation. Am Rev Respir Dis 1993; 147: 1151-6.

14. Cochrane WJ, Afolabi OA. Investigation into the nutritional status, dietary intake and smoking habits of patients with chronic obstructive pulmonary disease. $\mathbf{J}$ Hum Nutr Diet 2004; 17: 3-11.

15. Schols AM. Nutrition and respiratory disease. Clin Nutr 2001; 20: 173-9.

16. Marquis K, Debigare R, Lacasse Y, LeBlanc P, Jobin J, Carrier G, et al. Midthigh muscle cross-sectional area is a better predictor of mortality than body mass index in patients with chronic obstructive pulmonary disease. Am J Respir Crit Care Med 2002; 166: 809-13.

17. Landbo C, Prescott E, Lange P, Vestbo J, Almdal TP. Prognostic value of nutritional status in chronic obstructive pulmonary disease. Am J Respir Crit Care Med 1999; 160: 1856-61.

18. Slinde F, Grönberg AM, Engström CP, RossanderHulthen L, Larsson S. Individual dietary intervention in patients with COPD during multidisciplinary rehabilitation. Respir Med 2002; 96: 330-6.

19. Steiner MC, Barton RL, Singh SJ, Morgan MD. Nutritional enhancement of exercise performance in chronic obstructive pulmonary disease: a randomised controlled trial. Thorax 2003; 58: 745-51.

20. Cai B, Zhu Y, Ma Y, Xu Z, Zao Y, Wang J, et al. Effect of supplementing a high-fat, low-carbohydrate enteral formula in COPD patients. Nutrition 2003; 19: 229-32.

21. Creutzberg EC, Wouters EF, Mostert R, WelingScheepers CA, Schols AM. Efficacy of nutritional supplementation therapy in depleted patients with chronic obstructive pulmonary disease. Nutrition 2003; 19: 120-7. 
22. Ferreira IM, Brooks D, Lacasse Y, Goldstein RS, White J. Nutritional supplementation for stable chronic obstructive pulmonary disease (review). Cochrane Database of Systematic Reviews 2005 (Issue 2). Art. No. CD000998.pub2. DOI: 10.1002/14651858.CD000998. pub2.

23. Statens Livsmedelsverk. Livsmedelstabeller. Stockholm: Liber Tryck; 1997.

24. FAO/WHO/UNU. Energy and protein requirements. Technical Report Series 724. Geneva: World Health Organization; 1985.

25. Symreng T. Arm anthropometry in a large reference population and in surgical patients. Clin Nutr 1982; 1: 211-9.

26. Durnin JV, Womersley J. Body fat assessed from total body density and its estimation from skinfold thickness: measurements on 481 men and women aged from 16 to 72 years. Br J Nutr 1974; 32: 77-97.

27. Kyle UG, Schutz Y, Dupertuis YM, Pichard C. Body composition interpretation. Contributions of the fat-free mass index and the body fat mass index. Nutrition 2003; 19: $597-604$.

28. Beaton GH, Milner J, Corey P, McGuire V, Cousins M, Steward E, et al. Sources of variance in 24-hour dietary recall data: implications for nutrition study design and interpretation. Am J Clin Nutr 1979; 32: 2546-59.

29. Siafakas NM, Vermeire P, Pride NB, Paoletti P, Gibson J, Howard P, et al. Optimal assessment and management of chronic obstructive pulmonary disease (COPD). The European Respiratory Society Task Force. Eur Respir J 1995; 8: 1398-420.

30. Becker W, Lyhne N, Pedersen A, Aro A, Fogelholm M, Thorsdottis I, et al. Nordic Nutrition Recommendations 2004: integrating nutrition and physical activity. Scand J Nutr 2004; 48: 178-87.

31. Kobayashi A, Yoneda T, Yoshikawa M, Ikuna M, Takenaka H, Fukuoka A, et al. The relation of fat-free mass to maximum exercise performance in patients with chronic obstructive pulmonary disease. Lung 2000; 178: 119-27.

32. Wouters E. Management of severe COPD. Lancet 2004; 364: 883-95.

33. Shoup R, Dalsky G, Warner S, Davies M, Connors M, Khan M, et al. Body composition and health-related quality of life in patients with obstructive airways disease. Eur Respir J 1997; 10: 1576-80.

34. Slinde F, Grönberg AM, Engström CP, RossanderHulthen L, Larsson S. Body composition by bioelectrical impedance predicts mortality in chronic obstructive pulmonary disease patients. Respir Med 2005; 99: 1004-9.

35. Oostenbrink J, Rutten-van Mölken M. Resource use and risk factors in high-cost exacerbations of COPD. Respir Med 2004; 98: 883-91.

36. Socialstyrelsen. Statistik om hälsa, vårdutnyttjande och sociala förhållanden. http://www.socialstyrelsen.se/; 2005.

37. Haderslev KV, Staun M. Comparison of dual-energy Xray absorptiometry to four other methods to determine body composition in underweight patients with chronic gastrointestinal disease. Metabolism 2000; 49: 360-6.

38. Schols AM, Wouters EF, Soeters PB, Westerterp KR. Body composition by bioelectrical-impedance analysis compared with deuterium dilution and skinfold anthropometry in patients with chronic obstructive pulmonary disease. Am J Clin Nutr 1991; 53: 421-4.

39. Steiner MC, Barton RL, Singh SJ, Morgan MD. Bedside methods versus dual energy X-ray absorptiometry for body composition measurement in COPD. Eur Respir $\mathbf{J}$ 2002; 19: 626-31.

40. Tramonte SM, Brand MB, Mulrow CD, Amato MG, O'Keefe ME, Ramirez G. The treatment of chronic constipation in adults. A systematic review. J Gen Intern Med 1997; 12: 15-24.

41. Akner G, Bosaeus I, Cederholm T, Echerlund I, Elmstihl S, Johansson I, et al. Näringsproblem i vård och omsorg - prevention och behandling. SoS-rapport 2000:11. Stockholm: Socialstyrelsen; 2000.

\author{
Frode Slinde \\ Department of Clinical Nutrition \\ Sahlgrenska Academy at Göteborg University \\ PO Box 459, SE-405 30 Göteborg \\ Sweden \\ Tel: +4631 7733723 \\ Fax: +4631829475 \\ E-mail: frode.slinde@nutrition.gu.se
}

